Отже, формування мультикультурної особистості учнів початкової школи становить навчально-виховний процес, що спирається на специфічні зміст і технології освіти i спрямований на набуття ними цінностей, знань, умінь i навичок мультикультурної освіти, їх творче використання у своїй діяльності й самовихованні себе як особистості, самосвідомого громадянина, який $\epsilon$ запорукою духовно розвиненого суспільства.

\title{
Література
}

1. Агаддулин Р. P. Поликультурная профессиональная компетентность современного учителя / Р. Р. Агаддулин // Проблеми сучасної педагогічної освіти. К. : Пед. преса, 2003. - С. 12-17. 2. Балицька I. В. Мультикультурное образование в США, Канаде и Австралии : автореф. дис. на соискание ученой ступени д-ра пед. наук : 13.00.01. / Балицкая И. В. - М, 2009. - 40 с. 3. Джуринский О. Н. Педагогика межнационального общения: Поликультурное воспитание в России и зарубежом: [учеб. пособ. для вузов]/ О.Н. Джуринский. - М. : Сфера, 2007. - 224 с. 4. Трасберг К. Мультикультурное образование : развитие идей и поиск путей их реализации в современном мире / К. Трансберг; под. ред. Л. Васильченко. - Тарту, 2004. - С. 7-12.

Лідія Коростіль

\section{СТАН ГОТОВНОСТІ ВЧИТЕЛІВ СІЛЬСЬКОЇ ШКОЛИ ДО ПРОФЕСІЙНОЇ САМООСВІТНЬОЇ ДІЯЛЬНОСТІ}

Коростіль Л. А. Стан готовності вчителів сільської школи до професійної самоосвітньої діяльності.

У статті розглядаються особливості самоосвіти вчителів сільської школи, висвітлюються результати проведеного самодіагностування стану готовності вчителів різних вікових категорій до самоосвітньої діяльності, зроблено порівняння та доведено, що здатність до самоосвіти у процесі практичної діяльності вчителя не тільки розвивається і поглиблюється, а й вигасає, змінює пріоритети в ії змісті. Це пов'язано з віковими змінами інтересів і можливостей людини, а також професійним вигоранням учителя.

Ключові слова: вчитель сільської школи, професійна самоосвіта, професійна самоосвіта вчителя сільської школи, готовність до самоосвітньої діяльності, самодіагностування, професійне вигорання.

Коростіль Л. А. Состояние готовности учителей сельской школы к профессиональной самообразовательной деятельности.

В статье рассматриваются особенности самообразования учителей сельской школы, освещаются результаты проведенного самодиагностирования состояния готовности учителей разных возрастных категорий к самообразовательной деятельности, сделаны сравнения и доказано, что способность к самообразованию в процессе практической деятельности учителя не только развивается и углубляется, а и угасает, меняет приоритеты в ее содержании, что связано с возрастными изменениями интересов и возможностей человека, а также профессиональным выгоранием учителя.

Ключевые слова: учитель сельской школы, профессиональное самообразование, профессиональное самообразование учителей сельской школы, готовность к самообразовательной деятельности, самодиагностирование, профессиональное выгорание. 
Korostil L. A. The state of readiness to professional self-educational activity among rural school teachers.

The article deals with the features of self-education of rural school teachers. The results of self-diagnostics aimed to determine the state of readiness of teachers of different age groups to self-educational activity are highlighted in the article. A comparison was made and it was proved that in practice teacher's capacity for self-educational activity not only develops and deepens, but also fades and changes directions. It happens due to age-related changes in human capabilities and interests, as well as teacher's professional burnout.

Key words: rural school teacher, professional self-education, professional selfeducation of a rural school teacher, readiness for self-educational activity, self-diagnostics, professional burnout.

Аналіз кадрового складу вчителів, які викладали хімію в загальноосвітніх навчальних закладах Сумської області в 2012-2013 навчальному році, дозволяє стверджувати, що 76\% учителів сільських навчальних закладів, незалежно від отриманої у вищому навчальному закладі спеціальності, мають педагогічне навантаження 3 3-х і більше різних навчальних дисциплін.

Щоденна підготовка до кількох уроків із різних навчальних предметів створює певні труднощі у виборі форм навчання, методів, засобів; вимагає постійної роботи 3 навчальними програмами, підручниками, іншими матеріалами [1]. До того ж, для вчителя, який викладає кілька предметів, не маючи спеціальної фахової підготовки 3 кожного навчального предмета, нагальною постає потреба в самостійному пошуку і засвоєнні ним нової інформації.

Отже, учитель сільської школи, перебуваючи в ситуації безперервної освіти, більшою мірою самонавчається, саморозвивається і самовдосконалюється через самоосвіту. Проте прагнення і продуктивність участі в безперервній освіті можливі за умови сформованої готовності до самоосвітньої діяльності.

Метою статті $\epsilon$ розкриття особливостей професійної самоосвіти вчителів сільських шкіл та висвітлення результатів самодіагностування стану готовності вчителів різних вікових категорій до самоосвітньої діяльності.

Аналіз психолого-педагогічної літератури 3 проблеми показав, що науковцями вивчені найважливіші питання теорії і практики самоосвіти:

- сутність, особливості й функції самоосвіти, іiі місце у професійній діяльності (С. Архангельський, В. Буряк, А. Громцева, Т. Землінська, Ю. Калугін, М. Піскунов та ін.);

- різні проблеми самоосвіти вчителя (Т. Браже, М. Заборщикова, О. Лебедєв, С. Елканов, С. Юдакова й ін.);

- самоосвіта як одна $з$ форм підвищення професійної майстерності вчителів і студентів (І. Барсуков, М. Бондаренко, Н. Бухлова, I. Вертилецька, В. Іщенко, Г. Коджаспірова, М. Косенко та ін.).

Питання щодо особливостей самоосвіти вчителів сільських шкіл залишаються ще мало вивченими.

Учитель нині перебуває під перехрестям чотирьох вогнів: вимагає держава, вимагають учні, батьки, вимагає власна душа. Держава вимагає неухильного дотримання і виконання навчальних програм, учні якісних знань, батьки вважають, що це школа гальмує розвиток їхнього чада, а вчитель хоче випускати у світ розумних і конкурентноздатних учнів [6].

Щоб відповідати вимогам, учитель будь-якого віку об'єктивно змушений бути 
мобільним, гнучким, інформованим, а також критично і творчо мислячим, суспільно активним, відповідальним, мотивованим до свого розвитку, навчання й освіти. У Державній програмі «Вчитель» зазначено, що педагогічні й науково-педагогічні працівники зобов'язані постійно підвищувати свій професійний рівень шляхом самоосвіти.

Професійна самоосвіта - це вагомий елемент безперервної освіти, що відбувається поза навчальним закладом шляхом самостійної роботи і зумовлена виробничими потребами. Відповідно до потреб зміст професійної самоосвіти педагога охоплює такі компоненти: загальноосвітній, предметний, психолого-педагогічний, методичний і особистий.

Тому під професійною самоосвітою вчителя ми розуміємо цілеспрямовану самостійну пізнавальну діяльність учителя, спрямовану на оволодіння загальнолюдським досвідом, методологічними і спеціальними знаннями, професійними вміннями й навичками, що дозволять досягти високого загальнокультурного рівня, професійної компетентності, підвищення результативності педагогічної діяльності, педагогічної майстерності й творчого ставлення до справи.

За дослідженням Г. Воложиної, професійна самоосвіта міських і сільських учителів має свої особливості, які залежать від чинників соціального, психологічного й економічного характеру, умов життя, традицій і моральних засад тієї місцевості, у якій вони проживають [3].

У вчителя сільської школи, порівняно 3 міською, інші умови життя: кількість підготовок до уроків складає до 24 на тиждень і часто не 3 фахових предметів; підсобне господарство, яке змушені тримати $87 \%$ учителів, не дозволяє заздалегідь спланувати самоосвітню діяльність та можливість відпочинку; неможливо опрацювати варіативні літературні джерела через їх відсутність; школи віддалені від методичних центрів, бібліотек; навчально-методична література застаріла тощо [6]. Сільський учитель також виробляє вміння продуктивної взаємодії 3 сільським населенням різного віку. Саме тому сільська школа завжди була і буде не тільки освітнім, але й соціокультурним центром, а вчитель, який перебуває у режимі постійної неперервної освіти, - творцем i перетворювачем освітньої та соціокультурної ситуації на селі [2].

Отже, самоосвітня діяльність учителя сільської школи передбачає: самонавчання (отримання нової інформації 3 предметів, які вчитель викладає не за фахом), самовдосконалення (вдосконалення знань i вмінь 3 фахових дисциплін) i саморозвиток (збагачення власного досвіду), а також має два напрями: розв'язання актуальних педагогічних завдань і соціокультурних завдань розвитку села. Обидва напрями взаємопов'язані - чим заможніше село, тим більша школа, більш професіональний і творчий колектив учителів і навпаки.

Виходячи 3 вище зазначеного, готовність учителя сільської школи до самоосвітньої діяльності ми будемо розглядати як здатність до постійного саморозвитку і самонавчання в контексті перспективних напрямків перетворення сільської школи та соціуму й розроблення педагогічних і соціокультурних проектів 3 урахуванням мінливих ресурсів сільського середовища [там же].

Поняття «здатність» тлумачиться в Українському педагогічному словнику як властивість індивіда, що визначає його можливість, спроможність, нахил до виконання певної діяльності [4, с. 135]. У нашому контексті - до самоосвітньої діяльності. Автор зазначає, що здатність зумовлюється рівнем знань, здібностей, 
умінь, навичок, особистісними якостями (риси характеру й темперамент, особливості емоційно-вольової сфери). Вона розвивається, поглиблюється у процесі практичної діяльності людини і значну роль у цьому відіграють природні нахили людини і іiі задатки [там же].

Отже, здатність до педагогічної самоосвітньої діяльності формується ще у виші, але розвивається, поглиблюється, набуває своєї індивідуальності у процесі практичної діяльності кожного вчителя.

Задля визначення готовності вчителів різного віку до самоосвітньої діяльності у 2013-2014 навчальному році на базі Сумського обласного інституту післядипломної педагогічної освіти було проведено самодіагностування вчителів природничих дисциплін. На думку науковців, самодіагностування педагогічної діяльності дозволяє перевести роботу 3 самоосвіти в режим активного саморегулювання та самокоригування, а також реалізувати одну із функцій методичної роботи стосовно конкретного педагогічного працівника- аналітично оцінювальну, сутність якої полягає передусім у критичному осмисленні наявного особистісно-професійного росту та його оцінка [5; 7].

Діагностувальна карта вчителя охоплювала питання, відповіді на які давали можливість оцінити сформованість таких компонентів самоосвітньої діяльності: мотиваційного, когнітивного, морально-вольового, гностичного, комунікативного, організаційного і само управлінського. Розглянемо їхню сутність [7, с. 12-15]:

Мотиваційний компонент - це потреба в постановці та розв'язанні пізнавального завдання, що виявляється в активному сприйнятті, пізнавальних інтересах, у потребі до самоконтролю.

Когнітивний компонент - розвиток професійно-предметної компетентності: рівень знань і вмінь з фаху, педагогіки, психології, методики та інформатики.

Морально-вольовий компонент - орієнтація вчителя на загальнолюдські норми моралі, на золоте правило етики в поєднанні з умінням досягти мети, рішучістю, наполегливістю, активністю, самостійністю, вимогливістю до себе і школярів.

Гностичний компонент - вміння отримати, проаналізувати та узагальнити інформацію, необхідну для формування наукових знань.

Комунікативний компонент - уміння встановлювати ділові i неформальні особисті стосунки з окремими учнями і групами учнів; ділове спілкування 3 іншими вчителями й адміністрацією школи; контакти 3 державними $\mathrm{i}$ громадськими організаціями; налагодження взаємодії з батьками учнів тощо.

Організаційний компонент - уміння швидко й ефективно застосовувати на практиці педагогічні знання, діяти з урахуванням надбаного досвіду і ситуації, що склалася.

Самоуправлінський компонент охоплює комплекс умінь: проектувальні, що передбачають визначення цілей, можливостей їх досягнення в конкретних умовах та комплексу відповідних завдань; конструктивні, які забезпечують оптимальний вибір і структурування навчально-виховної інформації та засобів педагогічної комунікації; процесуальні- вміння щодо організації навчально-виховного процесу, адекватної його реалізації та створення необхідної психологічної основи; встановлення зворотного зв'язку- вміння практично використовувати інформацію зворотного зв’язку, необхідну для об'єктивного оцінювання результатів самоосвіти і оперативного внесення коректив.

Під час діагностування визначено три категорії вчителів з різним педагогічним стажем: 1 категорія зі стажем до 10 років, 2 категорія - від 10 до 20 років і 3 
категорія - понад 20 років. Їхні показники порівнювалися між собою. Також дев'ять оцінок були об'єднані в три рівні розвитку: «середній» (1-4 бали), «достатній» (5-7 балів) і «високий» (8-9 балів). Уважаємо, що «початковий» рівень учителі опановують у виші.

Аналіз результатів самодіагностування вчителів дозволив визначити особливості сформованості компонентів готовності до самоосвітньої діяльності у педагогів трьох вікових категорій.

У всіх категорій педагогів самооцінка мотиваційного компонента знаходиться на нижній межі «достатнього» рівня. На нашу думку, це пов'язано 3 тим, що в умовах сільської школи вчителю ні $з$ ким конкурувати і питання соціального престижу не стоїть для них так гостро.

При цьому, вчителі зі стажем роботи до 10 років у змісті самоосвіти віддають перевагу психолого-педагогічному компоненту, а методичний ставлять на останнє місце. Вони працьовиті, інформаційно грамотні, але не зовсім відповідальні. У них $є$ бажання і прагнення працювати по-новому, бути актуальними, проте ще недостатньо сформовані організаційні, комунікативні й самоуправлінські вміння, тому ведуть себе не зовсім упевнено.

Учителі зі стажем від 10 до 20 років уже мають достатній досвід педагогічної, психологічної й методичної роботи. У змісті самоосвіти всі компоненти вважають вагомими, але перевагу віддають методичному. Вони допитливі, креативні й цілеспрямовані; мають уміння мобілізуватися, змінювати власну систему діяльності за рахунок акумулювання й використання досвіду колег. У цій категорії вчителів відбувається майже повний збіг зовнішніх і внутрішніх потреб з їх професійними й особистими можливостями. Тому їх самоосвітня діяльність спрямована як на професійну, так і на особистісну самореалізацію в соціумі села. Саме ця категорія вчителів частіше за інших бере участь у професійних конкурсах, різноманітних проектах, навіть не пов'язаних із професійною діяльністю.

Досвідчені вчителі зі стажем роботи понад 20 років позитивно ставляться до процесу самоосвіти, але більше уваги приділяють самоаналізу власної професійної діяльності (узагальнюють педагогічний досвід, діляться ним 3 колегами, ведуть наставницьку роботу). Вони вносять корективи щодо змісту системи роботи, але кардинально іiї не змінюють. Компоненти професійної самоосвіти поступаються місцем особистісній самоосвіті (удосконалювання знань про здоров'я, родинні стосунки, хобі). Зазначимо, що ця категорія вчителів прагне самореалізації не лише в професійному, а в іншому виді діяльності, яка більш відповідає їхнім особистісним, життєвим інтересам.

Отже, у процесі практичної діяльності здатність педагога до самоосвіти не тільки розвивається і поглиблюється, а й вигасає, зумовлюючи зміни пріоритетиів у змісті. На нашу думку, пояснення цього явища криються в умовах роботи сільського вчителя (кілька предметів на ставку, багато підготовок на тиждень, недостатня кількість учнів у класі, відсутність сучасного методичного забезпечення, наявність господарства тощо), які призводять до раннього професійного вигорання, а також в особливостях вікової психології особистості.

\section{Література}

1. Армейська Л. В. Самоосвіта - ефективна умова формування професійної компетентності вчителів малочисельних навчальних закладів у системі післядипломної освіти [Електронний ресурс]/ Л. В. Армейська. - Режим доступу : file://D:/Документы/ Загрузки/pspo_2013_39\%283\%29_4.pdf. 2. Бухлова Н. В. 
Особистісно-професійне зростання вчителя сільської школи в умовах неперервної освіти [Електронний ресурс]/ Н. В. Бухлова. - Режим доступу : http://ippo.dn.ua/assets/Uploads/ Vseukrainskyforum/ Buhlova.doc 3. Воложина А. В. Сравнительный анализ профессионального самообразования сельского и городского учителя [Електронний ресурс]/ A. В. Воложина. - Режим доступу : http://nsportal.ru/vuz/psikhologicheskie-nauki/library// sravnitelnyy-analiz-professionalnogosamoobrazovaniy 4. Гончаренко С. У. Український педагогічний словник / Семен Гончаренко. - К. : Либідь, 1997. - 376 с. 5. Гуц 3. Самоосвіта - самоціль чи необхідність / З. Гуц // Завуч. - 2005. - № 28. - С. 7. . Дзега В. Д. Сільська малокомплектна школа в умовах експериментальної діяльності / В. Д. Дзега // Особливості інноваційної діяльності сільської малокомплектної школи : матеріали науково-практичної конференції (Черкаси). 2010. 7. Радченко А. С. Моніторинг професійної педагогічної компетентності вчителя/ А. Є. Радченко // Управління школою. - 2005. - № 35-36. - С. 12-15.

\section{ПЕДАГОГІЧНА ТЕХНОЛОГІЯ ФОРМУВАННЯ ЛІНГВІСТИЧНОӤ КОМПЕТЕНТНОСТІ МАЙБУТНЬОГО ВЧИТЕЛЯ ПОЧАТКОВОЇ ШКОЛИ}

Мамчич О. Б., Калініна І. П. Педагогічна технологія формування лінгвістичної компетентності майбутнього вчителя початкової школи.

Статтю присвячено дослідженню проблеми формування лінгвістичної компетентності майбутніх учителів початкової школи у вищих педагогічних навчальних закладах. Обгрунтовано педагогічні умови та розроблено систему формування мовної компетентності, що передбачає методику формування, комплекс тем і завдань теоретичного і практичного характеру.

Ключові слова: лінгвістична компетентність, комунікативна компетентність, лінгвостилістичний аналіз тексту.

Мамчич О. Б., Калинина И. П. Педагогическая технология формирования лингвистической компетентности будущего учителя начальной школы.

Статья посвящена исследованию проблемы формирования лингвистической компетентности будущих учителей начальной школы в высших педагогических учебных заведениях. Обоснованы педагогические условия и разработана система формирования языковой компетентности, которая включает методику формирования, комплекс тем и заданий теоретического и практического характера.

Ключевые слова: лингвистическая компетентность, коммуникативная компетентность, лингвостилистический анализ текста.

Mamchich O. B., Kalinina I. P. Pedagogical technology of forming the linguistic competence of future teacher of primary school.

The article is devoted to the research of forming of linguistic competence of future elementary school teachers in pedagogical higher schools. The pedagogical conditions of forming linguistic competence, the system of forming includes the forming methods, the theoretical and practical complex of subjects and tasks.

Key words: linguistic competence, communicative competence, linguistic analysis of texts. 